\title{
Competencies of trainee secondary school teachers in using common ICT tools and Office software packages and the impli- cations for successful integration of ICT in the Mauritian education system
}

Christian Li Luen Ching Mauritius Institute of Education
Compétences des élèves-maitres de l'école secondaire quant à I'utilisation des suites de logiciels bureautiques et des outils TIC courants et leurs implications pour une intégration réussie des TIC dans le système d'éducation de lîle Maurice

\section{bstract}

This study presents an analysis of a research survey conducted to determine the competencies of trainee teachers in using common ICT tools and software in teacher education programme at Mauritius Institute of Education (MIE). The collected data were analyzed quantitatively to calculate the different percentage distributions. The overall results of the

survey showed that the participants were well versed in the use of the common office software and were of different level of competencies based on the tasks listed. This article also seeks to advance some views on the challenges for successfully integrating ICT in the education system in Mauritius.

Keywords

ICT; in-service training, comptencies, training objectives, empower

Résumé

Cette étude présente une analyse d'un sondage de recherche visant à déterminer les compétences des élèves-maîtres du programme de formation des enseignants de I'Institut d'éducation de Maurice en ce qui a trait à l'utilisation des logiciels et des outils TIC courants. Les données recueillies ont fait l'objet d'une analyse quantitative afin de calculer les différentes distributions en pourcentage. Les résultats globaux du sondage montrent que les participants connaissent très bien l'utilisation des logiciels bureautiques courants et se situent à divers niveaux de compétences selon les tâches énumérées. Le présent article expose également quelques points de vue sur les défis à relever pour une intégration réussie des TIC dans le système d'éducation mauricien.

Mots-clés

TIC, perfectionnement, compétences, objectifs de formation, autonomisation

\section{Introduction}

The Mauritius Institute of Education (MIE) is the primary provider of professional development programmes for practicing teachers and the sole provider of pre-service training programmes for primary school teachers. With the vision of the government to make Mauritius a cyber island, tremendous effort has been done to disseminate the awareness of the potential of using Information and Communications Technologies (ICTs) in teaching and learning. The MIE has responded positively by introducing at least an ICT module in all its teacher education programmes (MIE Strategic Plan 20072015 Report, Jan. 2007). Teachers are faced with new challenges to adopt ICT tools into their working practices. Angeli and Valanides (2009) pointed out that many teacher education programmes have recognized the challenges associated with developing teachers' abilities to use technology in their classrooms. Teachers have to be technologically empowered so that they can use ICT in their teaching and learning. It is imperative that teachers are exposed to effective use of ICT in their training (Steketee, 2006). Initially, from my own experience and interaction with the practizing teachers, this issue of enabling technology integration was seen to be an unproblematic one. Eventually it was found that a number of practising teachers are experiencing doubts in how to integrate effectively ICT tools into the existing curriculum. Condie and Livingston (2007) also found in a study that while some teachers continue to display a reluctance to engage with new technology, others remain fearful of trying new approaches which they perceive might have a negative impacts on examination results. The major barriers may be lack of confidence, lack of competence or lack of access to ICT resources. Confidence, competence and accessibility are critical components of technology integration in schools. This prompted me to engage in a research 
survey to determine the competencies of trainee secondary school teachers in using common ICT tools and office software packages in joining teacher education programme at MIE. Needless to say that the role of ICT in education has changed radically with the advent of the new technologies.

The outcomes of this study would be helpful to engage further in-depth studies in the use of the ICT tools. According to Bransford (1999) the appropriate use of ICTs can catalyze the paradigmatic shift in both content and pedagogy. If designed and implemented properly, ICT-supported education can promote the acquisition of the knowledge and skills that will empower students for lifelong learning. Computers and Internet technologies enable new ways of teaching and learning to take place, which would constitute a shift from a teacher-centred pedagogy to one that is learner-centred. Consequently, the impact of ICT on the curriculum is perceived to be positive as it impacts on the 'what' and the 'how' of the curriculum.

This paper drawing from the findings of the research, seeks to argue further on the ways in which Mauritius can succeed in integrating ICT, especially taking into consideration the fact that there is a gap between the expectations of the policy makers and the teachers on the one hand and students at the receiving end. If teachers share the values expressed within a technology related policy and understand its implications, this policy is able to influence practice (Kennewell, Parkinson and Tanner, 2000).

\section{Background study}

There are a number of issues that may hinder teachers to know how to use ICT effectively in their teaching. In view of the importance of ICT for education, UNESCO and its partners have conducted an extensive consultation to identify the competencies that teachers should develop. This resulted in a document titled as UNESCO ICT-Competency Framework for Teachers (ICT_CFT) which was first published in 2008 and revised in 2011.

The UNESCO (2011) ICT Competency Framework for teachers emphasizes that it is not enough for teachers to have ICT competencies but to be able to teach these competencies to their students. Teachers need to help students to become collaborative, problem-solving and creative learners through using ICT. The Framework is arranged in three approaches to teaching: technology literacy, knowledge deepening and knowledge creation. These approaches are seen as part of a development continuum and each approach has different implications for education reform and improvement. ICT plays a unique but complementary role in each of these approaches, with new technologies requiring new teacher roles, new pedagogies and new strands to teacher education. The successful integration of ICT depends on the ability of teachers to merge technology with new pedagogies. On the basis of the guidelines provided in this document that has prompted me to conduct an initial survey research on the competencies of trainee teachers.

Teachers need to have ICT skills because they are the agents for developing positive attitudes towards ICT in the young generation of the Information Age. This is the case for teachers who are already in service, are reluctant or show resistance or even reject the use of ICT in their teaching and learning. One possible consequence of the teachers' resentment towards ICT may result in a dysfunction in their teaching to the young generation of students. Due to the very nature of our educational system, we cannot ignore those teachers. Since 1975 most of the practizing teachers before joining their teaching 
career had never followed any professional courses in ICT before. We have to make them functional with the right attitude and skills. It is with this objective in mind that the need to conduct this research among the secondary school teachers emerged.

ICT has become a common tool for teaching and learning. Teachers are exposed to a lot of sources of information through the Internet. However, without proper guidance with someone alert to the proper use of such tools, the use of ICT might become dysfunctional for some teachers. In this context in-service teachers cannot be insensitive to this issue. The debate that a lot of the previously essential skills of teachers are becoming obsolete and even useless is well alive. Many in-service teachers of older age may not have had the opportunity to take any computer course. Research conducted by a number of international studies have shown that secondary school teachers lack competencies on the use of ICT as a pedagogical tool in teaching and learning process (Nihuka and Voogt, 2011). Important barriers to use of ICT in teaching and learning have been identified such as resistance to change, negative attitudes towards computers, constraints on training and support, cost, and a lack of appropriate types of technology (Peeraer and Van Petegem, 2009). These may be underlying reasons for prospective teachers' negative perceptions of ICT use in the teaching process (Hismanoglu, 2012). Consequently, it is imperative that an initial research study be carried out to find out the current level of their ICT competencies so as to equip them to become fully functional. Knowledge of the teachers' ICT competencies is a vital component for the strategic planning process of future courses in ICT.

\section{Sample of participants}

A total of 212 questionnaires had been collected among which 208 questionnaires have been validated. The sample of the participants are mainly in-service secondary school teachers in three Professional Development Programmes namely: Teacher's Diploma, Bachelor in Education and Post Graduate Certificate of Education. It is interesting to note that more than two thirds of the teachers (69.5\%) were married which is an indication that the majority of teacher trainees have a married life, family responsibility and consequently less time to engage in the use of innovative technology such as the use computers.

\section{Research objectives}

The research objectives of the study are to:

1. determine the teachers' competencies in using common ICT tools and office software packages such as Word, Spreadsheet, Presentation Software, Databases and the use of Internet in joining their teacher training programme.

2. find out the availability of technological resources at schools.

3. determine the challenges for successful integration of ICT in schools. 


\section{Methodology}

\section{Instrument for Data Collection}

In order to assess the ICT competencies of the teachers in different subject areas, a three-paged questionnaire was designed to collect data for this study. The questionnaire for this study was testpiloted with 36 in-service trainee teachers. Following the pilot testing, some items included in the questionnaire had been improved or amended to finalise the intrument administered. In the initial part of the questionnaire, information such as the objectives, the purpose and confidentiality of the respondents dealing with the informed consent, had been clearly laid out. The questionnaire consists of four major parts. Part 1 is to gather background information on the participating teachers, their ICT skills prior to joining the training programme, whether they have a computer at home or at school with Internet access and number of hours spend on them. Participants have to check the boxes as it applied to them, which included their programme of study \& year, gender, age, status, years of teaching experience, possess a computer and access the Internet. In Part 2, participants have to rate a list of common office software such as Word Processing, Spreadsheet, Databases, Presentation Software, Internet and other tools as a self-reported assessement of their level of competence prior to joining the teacher training programme. In the sub-part, participants have also to assess their own current skills related to using computers by ticking in a checklist of 12 computer operation skills. In part 3 , participants have to indicate how often they use computers and other ICT tools in a list of 12 common computer tasks. Part 4 of the questionnaire is to determine the kinds of technology resources made available for teachers in their respective schools from a list of 8 technology resources.

\section{Results and findings}

\section{Background Profile}

Almost $57 \%$ of the individuals from the sample were female as shown in Table 1 . The age distribution of the teachers in the sample showed that more than two third of the individuals (70\%) were less than or equal to 35 years of age.

\begin{tabular}{llll}
\hline Age Category (Yrs) & Female & Male & Total \\
\hline $20-25$ & 11.1 & 7.7 & 18.8 \\
$26-30$ & 14.9 & 9.1 & 24.0 \\
$31-35$ & 15.4 & 12.0 & 27.4 \\
$36-40$ & 8.2 & 4.3 & 12.5 \\
$41-45$ & 3.8 & 1.9 & 5.7 \\
$46-50$ & 2.9 & 6.3 & 9.2 \\
$51-55$ & 1.0 & 1.4 & 2.4 \\
\hline Total & 57.3 & 42.7 & 100 \\
\hline
\end{tabular}

Table 1

Distribution of teachers by gender for different age groups 
As regards to their teaching experience, the majority of teachers evaluated at $80.5 \%$, had a professional experience of 15 years or less. Only $7.6 \%$ of the teachers recorded had more than 25 years of teaching experience (Table 2).

\begin{tabular}{lc}
\hline Experience & \% Teachers \\
\hline $1-5$ & 31.5 \\
$6-10$ & 30.5 \\
$11-15$ & 18.5 \\
$16-20$ & 8.1 \\
$21-25$ & 3.8 \\
$>25$ & 7.6 \\
\hline
\end{tabular}

Table 2

Percentage distribution of teachers by experience

From Part 1 of the survey questionnaire, it was found that a low percentage of $14.3 \%$ of teachers did not have a computer at home. $28.7 \%$ of teachers used the computer at the MIE and $62.9 \%$ at school. Only a negligible percentage of $8.4 \%$ used the computer at some other places.

For those having a computer at home, about three quarters of the teachers indicated being connected to Internet. Teachers not only have access to the Internet but need to learn the technical skills needed to use ICT productively for working with new technology-based learning environments.

With respect to the use of ICT in their course (apart from the ICT module) at the MIE, 69.5\% of teachers used the ICT tools in their course (apart from the ICT module).

\section{Current level of competencies}

\begin{tabular}{llllcc}
\hline Application Packages & Excellent & Good & Fair & Little & None \\
\hline Word Processing & 22.7 & 43.6 & 17.5 & 13.7 & 2.4 \\
Spreadsheet & 6.4 & 29.1 & 31.0 & 22.2 & 11.3 \\
Database & 4.1 & 13.8 & 24.1 & 26.2 & 31.8 \\
Graphic Presentation & 8.1 & 22.8 & 23.4 & 26.4 & 19.3 \\
Internet & 18.2 & 29.8 & 24.7 & 19.7 & 7.6 \\
\hline
\end{tabular}

Table 3

Percentage distribution of teachers with their current self-assessed level of competence

According to the data gathered in Part 2 of the questionnaire, most of the teachers have self-assessed that they are good and proficient in all the different application software packages as indicated by the high percentages in Table 3. Competence in office automation software (Word processing and Spreadsheet) was more pronounced among the teachers compared to the other software. According to Jonassen et al., (2008), ICT as a pedagogical tool involves the use of software applications to solve problems, to extend student capabilities, to create products or communicate and share their perspectives with each other. 


\begin{tabular}{lccc}
\hline \multicolumn{1}{c}{ Tasks } & No Skill & $\begin{array}{c}\text { Somewhat } \\
\text { with some skill }\end{array}$ & Have the skill \\
\hline Simple computer operations such as switch On/Off, Start & 5.5 & 6.6 & 87.8 \\
Load \& Run a software & 5.5 & 9.6 & 84.9 \\
Display directory of disk & 10.5 & 13.0 & 76.4 \\
Copy \& Save files & 6.5 & 12.1 & 81.4 \\
Create a Word-Processed document & 8.5 & 11.4 & 80.1 \\
Insert graphics in document & 22.3 & 21.8 & 55.8 \\
Use a simple spreadsheet to present data & 17.1 & 21.1 & 61.8 \\
Prepare a PowerPoint presentation & 27.9 & 25.4 & 46.7 \\
Use a WWW search engine & 13.6 & 19.2 & 67.2 \\
Send \& respond to an e-mail & 17.8 & 20.8 & 61.4 \\
Develop a multimedia document or web page & 60.9 & 25.4 & 13.7 \\
\hline
\end{tabular}

\section{Table 4}

Self assessment of own current skills related to using computers to do the listed tasks

Furthermore, the majority of the teachers self assessed themselves to have the skills to perform most of the listed tasks as mentioned in Table 4. Only 13.7\% of the teachers have the skills to develop a multimedia document or web page. $27.9 \%$ of the teachers have also indicated that they do not have the skill to prepare a slide show using PowerPoint software which is a common tool used as teaching aids. Several studies have been investigated computer self-efficacy or/and actual ICT use of trainee teachers. Thompson et al. (2003) indicated that technology should be infused into the entire teacher education programmes so that trainee teachers can understand the reasons behind using technology.

\begin{tabular}{lcccc}
\hline \multicolumn{1}{c}{ Task } & Do not Use & $\begin{array}{c}\text { One or two } \\
\text { times }\end{array}$ & More often & At all times \\
\hline Record or calculate student grades & 34.1 & 36.1 & 22.0 & 7.8 \\
Make handouts & 30.1 & 37.9 & 23.8 & 8.2 \\
Write lessons plans & 30.2 & 28.8 & 32.2 & 8.8 \\
Word process assignments & 9.2 & 12.1 & 27.7 & 51.0 \\
Get info or pictures from Internet & 12.2 & 30.4 & 36.8 & 20.6 \\
Search info from Internet for assignment & 6.8 & 18.4 & 40.1 & 34.8 \\
Exchange computer files with other teachers & 34.8 & 32.4 & 22.1 & 10.8 \\
Correspond with others teachers by e-mail & 34.0 & 30.1 & 21.8 & 14.1 \\
Use camcorders, digital cameras or scanners & 69.9 & 17.5 & 6.8 & 5.8 \\
Post work, suggestions for resources, ideas and opinion on & 79.1 & 15.9 & 2.0 & 3.0 \\
the Internet & & & & \\
\hline
\end{tabular}

\section{Table 5}

Percentage distribution of teachers on the frequency of using computers and other ICT tools 
As regards to the frequency of using computers and other ICT tools, it was found that above $30 \%$ of teachers were not using computers at most of the tasks listed in Table 5. It is interesting to note that 51 $\%$ of teachers use computers at all times to word process their assignments and only $6.8 \%$ of teachers do not use the Internet to search information for assignment. $69.9 \%$ of teachers mentioned that they do not use camcorders, digital cameras or scanners in class.

\section{Technology Resources}

\begin{tabular}{lcc}
\hline \multicolumn{1}{c}{ Resources } & Available & None \\
\hline Overhead Projector & 44.2 & 55.8 \\
Data Video Projector & 21.2 & 78.8 \\
Desktop Computer of own use & 37.4 & 62.6 \\
Access to Computers in lounge or staff room & 34.3 & 65.7 \\
Suitable software in subject area & 26.2 & 73.8 \\
Access to Internet in work place & 57.3 & 42.7 \\
Use of a computer printer & 55.2 & 44.8 \\
Use of a digital camera or a scanner & 16.6 & 83.3 \\
\hline
\end{tabular}

\section{Table 6}

Percentage distribution of the kinds of technology resources made available for teachers

In general, above $50 \%$ of the teachers indicated that they have none of the kinds of technology resources were made available to them, namely overhead projector, data video projector, computers at schools for their own use, suitable software in their subject area and use of a digital camera or scanner. The least available resources for teachers were data video projectors and a digital camera or scanner. The most available resources in the work place were the Internet and a computer printer.

\section{Discussions}

This study has shed some light on the background profile of the teachers, how frequent teachers use computers and other ICT tools and the availability of technological resources at schools. The research was carried out through survey questionnaires which allow teachers to respond to the items in private. All the teachers within the sample were attending courses at the MIE.

It has been found that the secondary school teachers in the sample were quite well versed in the use of common software packages prior to joining their training programmes. The majority of the teachers indicated that they could use, with no difficulty, the common application software packages namely word processing, spreadsheet, database, graphic presentation and the Internet. This had also been confirmed by the teachers' self-reported assessment of their own current skills in performing a list of tasks. The teachers responded that they had the necessary skills to perform most of the listed tasks from the Table 4 . Due to the government policy to make the country a cyber-island, opportunities of training to use office software tools at a very low cost have been provided to teachers so as to develop their basic computer literacy. Consequently, a large number of primary and secondary school 
teachers had followed the basic computer literacy course previously run by the National Productivity and Competitiveness Council (NPCC) and subsequently by the National Computer Board (NCB). Besides this, in most households in Mauritius there are more and more families acquiring computers for their personal use. This was encouraged through a number of incentives such as a very low interest loan for buying computers and printers. Most teachers in the survey also confirmed that they had a computer at home and had Internet access. This may explain the high percentage of teachers who were proficient and confident in the use of computers prior to joining MIE.

In this study the availability of technology resources and support was also investigated. More than 50\% of the teachers indicated that they did not have the kinds of technology resources available, namely, overhead projector, data video projector, computers at school for their own use, suitable software in their subject areas and the use of digital camera or scanner. Technology resources at schools are often inadequate or even unavailable. There is a strong perception that technology resources and support have a contributive impact on the teachers for using or not using computers in their training. It is evident that schools provide only those technological facilities (computers and Internet access) that are available freely from government contributions. Thus $75.7 \%$ of teachers indicate that they have computers and Internet access. Computers have been provided by schools so as to qualify them for grants by the authorities (PSSA Assessment Form, 2014) and to be able to run computing courses. Similarly, Internet facilities are provided freely by the Ministry of Education and Human Resources. Besides these two facilities, it is evident that very few schools provide additional support that would make inclusion of ICT possible. This may be a major factor influencing the use of ICT by teachers. Some teachers reported that they have little or practically no opportunities other than ICT teachers to make use of computer facilities in their school.

According to studies carried out, a gap exists between what trainee teachers are taught in their courses and how teachers use technology in classroom (Ottenbreit-Leftwich et al., 2010). Among the factors that have been identified to explain why a gap exists between actual and expected use of technology were: insufficient access to technology (Dawson, 2008) and lack of technology skills (Teo, 2009).

Concerning the frequency of using computers and other ICT tools, teachers in the survey were of different level of competencies based on the type of tasks listed. It had been found that about one third of the teachers were not using computers at all levels in their teacher training. A significant number of teachers $(51 \%)$ reported that they use computers at all time to do their assignments for their MIE courses. Though teachers called themselves confident users of their chosen ICT devices and applications, it is doubtful if they were right about the assessment of their own level of confidence. Based on the findings, it is evident that teacher training needs to take into account the nature of support provided to teachers. There is a need to increase motivational strategies by incorporating ICT across the teacher training curriculum. Failure to do so will make ICT appear to be only the concern of ICT teachers. MIE will be reproducing the same model available in schools where Computer Science is the concern of the computer teacher only. What needs to be done is that the computer teacher must be empowered to provide support to teachers of other subject areas to embed ICT in their teaching. 


\section{Conclusion}

The use of an ICT tool is rather personally intrinsic in nature that can only be beneficial if there is support and obligation to use the tools in schools. It is when all these elements are acquired that teachers will use the ICT tools. Another interesting issue that can be pointed out is that teachers at MIE have an obligation to use ICT in their courses but when they are at school they have no obligation to use ICT tools in their teaching. Even in certain schools the management discourage their teachers to use the facilities of the computer room if they are teaching subjects other than computer science. In this context, a distributive cascade training model can be used. Computer teachers will be trained to become first level trainers and then will train their colleagues in their respective schools. They will initiate teachers of other subject areas to incorporate technology in their teaching. They will become the instrumental help to motivating their peers. Ono and Ferreira (2010) rightly pointed out that the cascade approach is often used to transmit knowledge or information from lower to upper group of teachers. In many developing countries, the cascading approach is commonly used to reach a great number of participants in a short period of time (Leu, 2004). For this model to work there is a need to create the obligation and motivation to use technology through policy decisions of the Ministry of Education and Human Resources and a redefinition of learning support at school.

The main limitations of this study pertain to the small sample size of participants and the context specific of the study. On top of this, the findings were based on percentage distributions gathered through questionnaires. In addition, it will be inappropriate to generalize the results. Further research and studies need to be conducted to confirm the findings and how to support teachers to make ICT an integral part of their teaching and learning.

An understanding of the competencies of trainee teachers in using common ICT tools and software is an important outcome of this research. While we have no alternative but to suceed in the digital age, educators have an essential role to play in the process. However, their success and determination depends largely on a clearer definition of the expecations of education system on the one hand, and, on the other hand, a thorough review of teaching at schools where the imperatives for integrating ICT is carried out with clearly defined objectives. However, the change and the challenge for the future of education is largely dependent on a workforce that has been there when the imperatives of digital age was minimal or almost non-existance, and who are still here and on whose shoulder rests the need to effect and ensure that the change takes place. An education system evolves, new needs come in and the need to effect the change with the existing workforce is always a challenge. More so, when we are in the presence of a tool where the client who is to be taught has skills that are probably more advanced than the one who is expected to teach. Given this paradoxical situation, the challenges for integrating ICT is yet more collosal. 


\section{References}

Angeli, C., \& Valanides, N. (2009). Epistemological and methodological issues for the conceptualization, development, and assessment of ICT-TPCK: advances in technological pedagogical content knowledge (TPCK), Computers E $^{\circ}$ Education, 52, 154-168.

Bransford, J. (1999). How People Learn: Brain, Mind, Experience, and School Washington D C: National Research Council

Condie, R., \& Livingston, K. (2007). Blending online learning with traditional approaches: changing practices, British Journal of Education Technology, 38(2), 337-348.

Dawson, V. (2008). Use of information and communication technology by early career science teachers in Western Australia. International Journal of Science Education, 30(2) 203-219

Hismanoglu, M. (2012). Prospective EFL Teachers' Perceptions of ICT Integration: A study of Distance Higher Education in Turkey. Educational Technology E Society, 15(1), 185-196.

Jonassen, D., Howland, J., Marra, R., \& Crismond, D. (2008). Meaningful learning with technology (3 ${ }^{\text {rd }}$ ed.) Upper Saddle River, NJ: Pearson.

Kennewell, S., Parkinson, J., \& Tanner, H. (2000). Developing the ICT capable school. London: RouteledgeFalmer.

Leu, E. (2004). The Patterns and Purposes of School-based and Cluster teacher Professional Development Programs. EQUIP/Working Paper No. 2 Washington, D.C.: U.S. Agency for International Development.

Nihuka, K. A. \& Voogt, J. (2011). Instructors' and students' competences, perceptions and access to E-learning technologies: Implications for E-learning implementation at the Open University of Tanzania. International Journal on E-Learning, 10(1), 63-85

Ono, Y., Ferrreira, J. (2010). A case study of continuing teacher professional development through lesson study in South Africa. South Africa Journal Of Education, 30, 59-74

Ottenbreit-Leftwich, A., Glazewski, K., Newby, T.,\& Ertmer, P. (2010). Teacher value beliefs associated with using technology: addressing professional and student needs. Computers E' Education, 55, 1321-1335

Peeraer, J., \& Van Petegem, P. (2009). The Use of ICT in Teaching Practice in Teacher Education in Vietman: Baseline Situation at the Start of 'The Year of ICT'. Unpublished Scientific Paper. University of Antwerp.

PSSA (2014). Assessment Form for Computer Room. Retrieved 20 th November 2014 form http://www.pssawebsite.mu/ English/Documents/Assessment\%20Forms/COMPUTER\%20ROOM\%202014.pdf

Steketee, C. (2006). Modelling ICT integration in teacher education courses using distributed cognition as a framework. Australasian Journal of Education Technology, 22(1), 126-144.

Teo, T. (2009). Modelling technology acceptance in education: a study of pre-service teachers. Computers $\Xi^{\circ}$ Education, 52 , 302-312

UNESCO. (2011). ICT Competency Framework for Teachers, Version 2.0. Retrieved $25^{\text {th }}$ November 2014 from http:// unesdoc.unesco.org/images/0021/0021/002134/213475E.pdf

\section{Pour citer cet article}

Li Luen Ching, C. (2016). Competencies of trainee secondary school teachers in using common ICT tools and Office software packages and the implications for successful integration of ICT in the Mauritian education system. Formation et profession 24(1), 56-65. http://dx.doi.org/10.18162/fp.2016.67 